\title{
ASSESSMENT OF MARKETING ACTIVITY MANAGEMENT IN TERRITORIAL UNITS: THEORETICAL-METHODOLOGICAL APPROACH
}

\author{
Serhii Smerichevskyi ${ }^{1}$, Tetiana Kniazieva ${ }^{2}$, Atia Walid ${ }^{3}$
}

\begin{abstract}
The subject of the study is a set of theoretical and methodological aspects of the development of organizational and economic relations that arise in the process of interaction of economic subjects while shaping the potential of territorial marketing as a factor of its socio-economic development. The purpose of the study is to substantiate the methodology for assessing the integral indicator of the territorial marketing functioning. The methodology of the presented study of marketing management in territorial units is based on the multivariate assessment of various economic entities that clearly shows the priorities and unevenness in the areas' development. Area economic entities themselves are interested in the area development and determine the direction of area development. Economic entities' direct residence and economic activity conducted by them in the area should be taken into account. This makes them serious experienced experts who are really interested in the effective and rapid development of their area. Economic entities themselves determine the measurable criteria for assessing the directions that they were originally offered. The "brainstorming" is used where the experts in the area development are involved. There is a joint process aimed at obtaining the most concrete and measurable results that actual state is assessed from 0 to 10 by the process participants based on personal observations and statistics. The evaluation of marketing results is based on the multicriteria socio-economic approach. The evaluation criteria should include the economic mechanism formation. This mechanism provides an effective interaction of market institutions and business entities in the area; selection of wholesale and retail organizational and economic forms, financial and credit and business services, as well as organizational and legal forms of trade and economic interregional ties; the markets system creation that is based on the priority provision of consumers and small owners interest; the choice of the most effective channels for goods movement, transportation, warehousing, material, financial, and information flows rationalization. The methodology for estimating the integral indicator of territorial marketing functioning that is presented in the work is based on the next indicators: financial stability, business activity, profitability, technical and technological stability, social sustainability, environmental sustainability that allows monitoring the functioning of the territorial marketing system. This methodology is universal since it allows evaluating areas of different industrial orientations and comparing them in order to identify the greatest functioning stability. Methodology for marketing research of areas potential is based on the system approach, complex consideration of conceptual principles of areas' marketing potential formation and development; key features of territorial marketing allow carrying out purposeful actions for the sustainable development of area marketing potential, within the framework of which the conditions of its formation are determined, and their aggregate acts as a point of growth of market marketing component of the economic potential of the territory and is the basis for constructing the model of infrastructure of the marketing potential of the territory, used to make sound and balanced management decisions; developed a methodology for assessing the integral indicator of the functioning of territorial marketing. Research conclusion: grounded methodology of research of territorial marketing potential that is based on the system approach, complex consideration of concepts of area marketing potential formation and development. The key features of territorial marketing are distinguished that allow carrying out purposeful actions for the stable development of the area marketing potential, within the framework of which the conditions for its forming are determined, and their complex serves as a point of growth of market marketing component of the area economic potential and is the
\end{abstract}

\footnotetext{
Corresponding author:

${ }^{1}$ National Aviation University, Ukraine.

E-mail: s f smerichevsky@ukr.net

${ }^{2}$ National Aviation University, Ukraine.

E-mail: tatiana.kniazieva2017@gmail.com

${ }^{3}$ International Humanities University, Ukraine.

E-mail: mgu@ukr.net
} 
Vol. 4, No. 4, 2018

basis for the creation of the infrastructure model for the area marketing potential that is used to make substantiated and balanced management decisions; a methodology for assessing the integral indicator of territorial marketing is developed.

Key words: territorial marketing, area marketing potential, regional policy, sustainable economic development, strategic planning of territorial marketing.

JEL Classification: M31, O38, R58

\section{Introduction}

Growing role of territorial marketing areas and changes in the strategies of territorial management are associated with a number of factors: change in the philosophy, principles, objectives of the area development, identification of the population as a real participant in the system of area planning, as well as change of the area authorities nature who become the main responsible persons for the area socio-economic development, including its improvement, safety and social protection of the population. The problems of territorial marketing are extremely relevant in Ukraine as far as they relate to such important areas as state and local government, investment attractiveness, European integration, competitiveness and strategic development of regions. The implementation of a regional policy aimed at eliminating disproportions between regions and their integrated development is strategically important for Ukraine. A progressive change in the socio-economic structure of the region that ensures the economical use of its resources and best satisfaction of area production needs means the development of the region.

Territorial marketing allows to look at the territorial unit from the point of view of its consumer value and, therefore, takes into account the needs and interests of the population. Territorial marketing becomes an integral part of the expanded reproduction process of area economic entities that is related with the production, promotion, distribution, and sale of products produced within the economic, geographical, and natural specifics of certain territorial units. Development of territorial marketing that is involved into the production process and goods and services circulation requires the study of the modern marketing theory, methodology and practice, as well as its consideration through the prism of economic entities' interests which are an integral part of the algorithm of decision-making. All it allows to purposefully affect the consumers' behaviour and stimulation mechanisms.

Among domestic researchers of this theme, A. Anoshkin, L. Grishina, R. Kozhukhivska, E. Popkova and others should be called. Many domestic works relate mainly to the role of marketing in increasing the investment attractiveness of regions, but more and more attention researchers pay to use of Internet technologies in marketing. Leading foreign specialists in territorial marketing are: F. Bencherif, P. Buonincontri,
Ph. Kotler, S. Anholt, Z. Megri, S. K. Rainisto, and others. Foreign researchers of territorial marketing pay the main attention in their works to the differentiated features of areas as a marketing object in comparison with goods and services, branding and the image of territories (countries, regions, cities), their impact to the socio-economic development, development strategies and tools of marketing of a particular area, global and local dimension of territorial marketing. Almost all cases are considered by authors in the context of the strategic development of promoted city or region. Practical recommendations for the planning and implementation of marketing campaigns are connected with the integrated approach to the management of the area and various aspects of its development.

Therefore, the goal of this article is to systematize domestic and foreign theoretical and methodological aspects of organizational and economic relations' development that arise in the process of economic entities' interaction while forming the area marketing potential as a factor for its socio-economic development and the methodology for assessing the integral indicator of territorial marketing functioning that is based on this justification.

\section{Theoretical and methodological principles of territorial marketing development}

The genesis of marketing is determined by the policy of the enterprises located on the territory, aimed at the sale of products manufactured with minimal costs. In the transition process from a deficient economy to the society of plenty, the need for a systematic search and development of new markets is growing. At the same time, marketing serves as a definite concept for the enterprise management and employees, the specific territorial unit authorities.

First of all, territorial marketing assumes taking into account the area's needs and interests in the pursued regional policy. In this case, it is a certain territory, designated by the territorial unit limits or entities that are a part of a single economic space. The unified economic space assumes goods, services, money free movement, as well as the free movement of labour within the boundaries of the territory; common language, land and capital that are necessary for a set of welfare production. 
Territorial marketing significantly differs from enterprise marketing, namely:

1) there is a wider range of marketing technologies that are used as far as the content of territorial marketing is complex;

2) territorial marketing is carried out on the territory defined by the boundaries (administrative, geographical, economic, informational and other), within which there are enterprises and organizations. The totality and functioning of enterprises and organizations create a single economic space that requires appropriate economic and organizational interaction: socioeconomic integration, share co-financing, the creation of temporary creative groups or other forms of management;

3) enterprise marketing focuses on the choice of the optimal distribution channels, the main task of territorial marketing is to search, create, and advertise such advantages of a territory that could be interesting for the potential labour force, investors, shareholders;

4) on any local territory, there is the concentration and intersection of economic interests of area population and subjects that live outside the area while it is necessary to recognize the parity (equality) of the interests of all subjects - the carriers of economic interests. Orientation to meet the needs of the indigenous population or those who permanently reside in the territory requires their interests to be prioritized that leads to inconsistency of interests and becomes the basis of the contradictions that require special measures for solving;

5) competitive advantages of the territory may not have value form that causes the diligence work to create the image of the territory as a special product.

The elaboration of territorial marketing development strategy is based on a number of prerequisites (Bagautdinova, 2012; Chandler, 2015; Isoraite, 2009; Runielt, 2014):

- firstly, it should be considered that the area has its own history and industrial structure including the industrial and social infrastructure that can and should be used for strategy development;

- secondly, the trajectory of the area development must be taken into account both in the historical retrospective and in the planned perspective. It can be achieved through the definition of possible "growth zones", which, in turn, assumes accelerated development of industries, sub-sectors or individual productions; determining the main directions for innovative development; reduction of the production of certain products, which may occur for various reasons (aging, resource base exhausting, etc.); accounting of direction of capital overflow and diversification, and so on;

- thirdly, the work over complex and targeted regional development programs should be based on the monostructure of the industry of domestic cities (especially in the mining and heavy industry). In such conditions, the accelerated development of light industry and services, including business services will be the purpose of these programs. In this regard, special attention should be paid to supply management as the most important component of the market.

Consequently, the essence of territorial marketing is based on socio-economic, investment-innovation, organizational and economic, institutional relations that are dominant in society. Certain requirements are putting forward to these relations:

- socio-economic relations - property relations, labour relations, economic interests forming, income distribution, national relations forming, social services distribution;

- organizational and economic relations - management and control, functions delegation, resources allocation, incentives, cooperation and specialization, regionalization;

- institutional relations - legal, normalization, external effects, contract, transaction costs;

- investment-innovation relations - between demand and supply, between investors and subjects of the territory, between households and the state, between the business and the state, between market availability and potential sellers.

\section{Area marketing potential and conditions for its forming}

Forming the area as an independent socio-economic entity assumes the creation of the potential, which will effectively form, correct, and develop the economy of the area. The area potential, from the marketing point of view, is understood the system of interconnected, interdependent, and interacting factors that provide an effective and progressive area development both nowadays and in the future. The combination of factors that characterise the area potential can be divided by a number of features:

- on a spatial basis, one distinguishes internal potential (that is, factors inherent in the region) and an external one (factors that operate in the region);

- on a temporary basis, territorial marketing is divided into the existing potential (area's resources) and possible (factors that can be used in the future or reserves);

- by genesis, the area potential is divided into natural, economic, and social. Effect of natural, economic and social factors on the regional development can be considered as one of the methods of conscious regulation of the regional reproduction territorial proportions in accordance with economic laws.

The area potential has a complicated hierarchy structure. In the most general form, it can be divided into natural, economic, social, human, national. The potential forming is determined by the specific conditions, which together give impetus to the development of the marketing component of the areas' potential, such as: raising the level of education and self-education, material incentives, personnel training, 
social benefits, moral stimulation, working conditions, income, unemployment cutting, raising life level and quality, ecology, economic indicators of households, etc. (systematized by (Isoraite, 2009; Simeon, Buonincontri, 2011; Chandler, 2015)).

Any territory existing in a competitive environment, regardless of its size, is forced to promote itself. The influence of various factors assists or does not the promotion in the local and foreign markets that form the marketing potential. Despite the deep economic crisis, reforms and transformations that take place in the country ensure forming competitive environment. In this regard, the behaviour of all economic entities is largely conditioned by rigid competitive conditions, which are formed both at the level of the country as a whole and at the level of specific regions, and therefore, the marketing component comes to the fore, providing a systematic development of the region.

As a result of all the above, it can be articulated that the area marketing potential is a set of natural, economic, social, national, human (labour, demographic) resources that ensure sustainable socio-economic development of the territory, its competitiveness and positioning in the domestic and world markets on the basis of expanded reproduction in accordance with economic laws.

However, it should be noted that the promotion of the area under the absence of its potential, arrangement, without creating the appropriate investment and innovative climate, and a number of other prerequisites are an ineffective business. In other words, the arrangement of the territory, its compliance with the public level of needs satisfaction are important prerequisites for the area competitiveness, its potential forming and development, without which to go to the marketing research is at least irrational. In this case, achieving the desired effect is unlikely. All factors that may influence the formation and development of the marketing potential of the territories should be taken into account (Figure 1).

The presented groups of factors clearly reflect the peculiarities of the area marketing potential formation. Therefore, external factors that shape the objective prerequisites for development must be taken into account, but the impact on them is difficult. At the same time, internal factors mainly related to general arrangement, controlled territories, and the possibility of their improvement and development are obvious, especially in the framework of the innovative process, an increase of investment attractiveness, the creation of competitive jobs, etc.

\section{The infrastructure of areas marketing potential}

In order to make reasonable and balanced decisions, it is necessary to monitor the trends of transformational shifts in the form of market research, despite the recognized inertia of the area structure. In each specific territory, the infrastructure peculiarities form its marketing potential; it is just a reflection of such shifts.

The infrastructure of the areas marketing potential consists of three blocks (Bagautdinova, 2012; Popkova, Dubova, 2013; Runielt, 2014):

- block I - social infrastructure: population service, education infrastructure, health infrastructure,

\section{FACTORS FOR FORMING THE MARKETING POTENTIAL OF AREAS}

\begin{tabular}{|c|c|c|}
\hline Internal Factors & 2 & External Factors \\
\hline $\begin{array}{l}\text { Level of education } \\
\text { Experience } \\
\text { Management style } \\
\text { Population income level } \\
\text { Labour motivation management } \\
\text { The volume of investment in } \\
\text { human capital development } \\
\text { Progressive forms of labour } \\
\text { organization } \\
\text { Safety and labour protection }\end{array}$ & $\begin{array}{l}\text { Improving the quality of } \\
\text { life of the population in } \\
\text { territorial units }\end{array}$ & $\begin{array}{l} \\
\text { State regional policy } \\
\text { The system of personnel training } \\
\text { and advanced training } \\
\text { New jobs creation } \\
\text { The demographic situation in the } \\
\text { region } \\
\text { Social policy that provides social } \\
\text { benefits } \\
\text { State of the city and the } \\
\text { countryside infrastructure } \\
\text { Quality of population life } \\
\text { Scientific and technological } \\
\text { progress } \\
\text { State of the labour market }\end{array}$ \\
\hline
\end{tabular}

Figure 1. Factors of areas marketing potential forming

Source: compiled by the authors (Isoraite, 2009; Simeon, Buonincontri, 2011; Anoshkin, 2014; Popkova, Dubova, 2013)) 
consumer services infrastructure, public transport infrastructure, culture, sport, and leisure facilities;

- block II - market institutional infrastructure: managing subsystem, organizational subsystem, material subsystem, information subsystem, credit and financial subsystem, personnel subsystem, regulatory subsystem, other (marketing organizations, leasing, innovations, etc.);

- block III - industrial infrastructure: enterprisesproducers, all types of transport, reservoirs, water supply, electricity, gas supply, heat supply, inter-branch and city heat networks, product quality systems.

The process of infrastructure formation and development is a combination of three blocks, each of which is necessary, important, and prone to changes. Especially large number of transformations due to the objective factors and the flexibility of processes occur in market institutional infrastructure, where the largest number of factors and regular and objective shifts take place. The influence on these shifts of new and changed economic interests of various economic entities is definitive. In addition, the interests of international business influence the areas' potential development, which is also facilitated by processes that have begun and entered into force over the years of economic transformation. These considerations allow making the following conclusions about territorial marketing:

1. The need to form the areas marketing potential and to usefully use its toolkit for diagnostic of the area state, the availability of competitive advantages and a generalization of the assessment of area economic policy.

2. The use of marketing tools and techniques that lies at the crossroads of regional economics and classical marketing cannot be considered a universal tool. If the area does not have, for example, transport infrastructure, marketing methods are very narrow.

3. Diagnostics of the area state through the prism of territorial marketing allows deeply and comprehensively analysing the problems of the area or territorial unit, ranking the tasks, identifying the contradictions and ways (methods) for their solution that will increase the area marketing potential. In other words, the complex use of marketing methods assumes the creation of certain prerequisites for widespread use of marketing tools in shaping the area potential.

Each area has many organizational and legal forms, a diverse range of resources, markets, potentials, and a variety of tools and opportunities. The territorial marketing research allows seeing more clearly the features and possibilities of each territorial formation, outlining the future as a separate area, as well as the directions of its possible integration processes, including integration to the international sphere.

The contradictions, which are the inconsistencies of interests at the regional level, are the most important prerequisite for developing the territorial marketing programs that shape its potential. It should be emphasized that territorial marketing contributes to the solution of emerging contradictions. It happens often indirectly due to the accounting of the most important affecting factors and scrupulous everyday work to establish the regional management mechanism.

\section{Methodology for the assessment of territorial marketing functioning}

In today's economic conditions that are characterized by complete economic independence of areas and responsibility for their livelihoods, as well as the uncertainty of external environmental factors, the main condition for their survival is to increase the efficiency and sustainability of functioning. The mechanism of territorial marketing stable functioning should promote in the best way area's autonomy and goals. In this regard, there is an objective need to develop tools for assessing the stability of the areas' functioning, including the impact of the marketing system. This will provide an efficiency increase and functioning stability and justify the practical significance in modern conditions. The following basic indicators of the sustainable functioning of territorial marketing can be integrated into the system under their evaluation:

- financial stability: equity, debt-to-assets, leverage, interest coverage, long-term investment security, capital, current assets to equity, current ratios, equity multiple; - business activity: ratios of capital turnover, inventory turnover, return on assets, sustainable growth, receivables turnover, finished goods turnover, working capital turnover, equity capital turnover borrowed capital turnover;

- profitability: ratios of return on assets, equity, current expenses, borrowed capital, fixed assets turnover, profit margin;

- technological stability: ratios of suitability, renewal, and growth of fixed assets;

- social stability: ratios of staff stability, average wages in the enterprise to the average wages in the industry, the provision of normative working conditions;

- ecological stability: ratios of warehousing, charges for air pollution by stationary objects, charges for air pollution by mobile objects, above-limit pollution payment.

This system completely reflects mathematical processing of the results of the areas integrated stability. To achieve the ratios' homogeneity, known method of normalizing the zero and negative values of the ratios is used. The method involves calculation of the normalized value of the negative ratio. The formula for determining the standardized value of each ratio looks like this:

$$
K_{N}=\frac{K_{n}}{K_{\max }},
$$

where $K_{n}$ - standardized value of ratio that reflects the state of enterprises in the nth analysed area;

$K_{\max }$ - the maximum value of ratio that is taken as standard;

$K_{N}$-value of the ratio of enterprises in the $\mathrm{n}^{\text {th }}$ territory. 
After determining the standardized ratios included in the corresponding generalized index, in the frame of this methodology, all the above indicators are combined into a single integral indicator. This indicator allows making a conclusion about the possibilities of surveyed enterprises' further development and is determined by using the expert evaluation method taking into account indicators heterogeneity:

$$
K_{\mathrm{int}}=\sum_{n=1}^{i} a_{n} \times A_{\text {agg }}
$$

where $K_{\text {int }}$ - integral performance indicator;

$a_{n}$ - the weight of the nth generalized stability index in the integral one, determined by the expert evaluation method;

$A_{a g g}-\mathrm{n}^{\text {th }}$ aggregate indicator of financial stability, business activity, profitability, technological, organizational, social, and environmental sustainability; $n$ - the number of generalized indicators that determine the integral functioning stability.

The proposed methodology is universal since it allows evaluating the areas of different branch directions and comparing them with each other in order to identify the greatest functioning stability. It also gives an opportunity to determine the dynamics of area functioning stability and to identify separate reserves of its growth for determining its ability to adapt to environmental changes. The application of a flexible calculation algorithm allows concluding that the area potential is sufficient for the analysed period of time. In Figure 2, the model of planning and management of territorial marketing is presented.

When constructing the model, an attention is focused on the program-target approach and methods of system

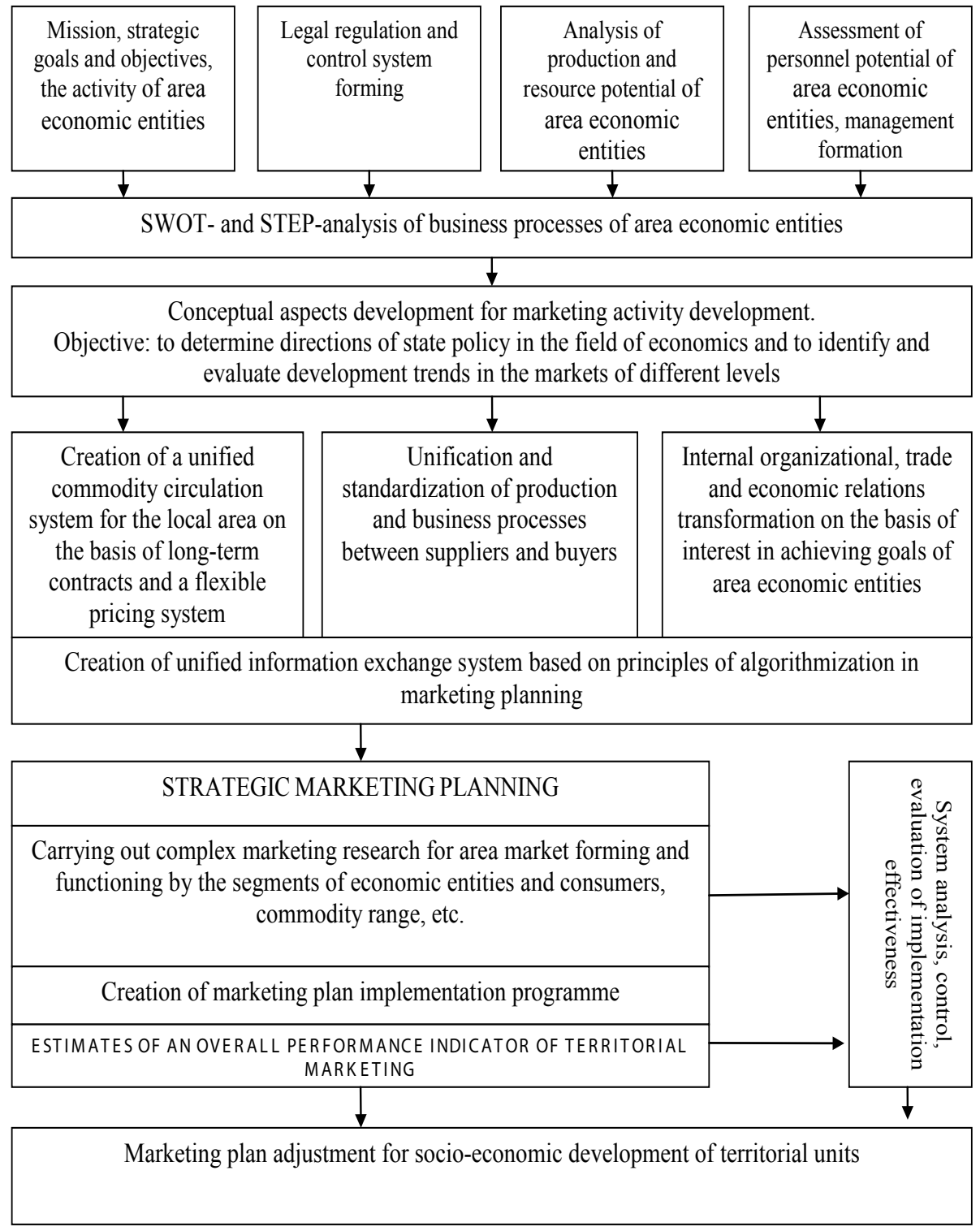

Figure 2. Model of territorial marketing planning and management system

Source: improved by the authors (Grishina, Yefimova, 2011; Kozhukhivska, Parubok, Petrenko, 2017; Isoraite, 2009; Megri, Bencherif, 2014; Venter, Jansen van Rensburg, 2014)) 
analysis. The complex nature of the model assumes the use of various tools and mathematical methods for representing marketing process objects. The developed model relates to the organizational-economic group of models. It allows optimizing the parameters of the measures in all phases of the marketing process in accordance with the given criteria, which contributes to solving the target task of marketing planning.

Taking into account the synergetic effect of marketing tools in the enterprises of the area and suggestions on the marketing planning system, it is offered to pay a particular attention to the complex use of marketing tools for planning the economic activity of the area subjects in goods and services design, production, and circulation, taking into account the peculiarities of existing and future state policy.

\section{Conclusions}

The theoretical comprehension of the socioeconomic foundations of territorial marketing allows making conclusions about the development of the general theory in the direction of its formation given the historical and practical preconditions regarding the area independent development within individual territorial formations, their associations, interconnected megapolis elements and interterritorial associations, the operation of territorial production complexes.

In the article, territorial marketing means a set of territory (territorial unit) management principles in order to achieve sustainable economic development, complete realization of economic interests of its population and means or methods for creating opportunities and conditions for attracting potential and real participants of transactions, which are carried out in this area and by area subjects. The development of territorial marketing strategy is based on a number of prerequisites: history and industrial-production structure survey; definition of possible "growth areas"; increased attention to the offer management as the most important component of the market. Territorial marketing is based on socio-economic, organizational and economic, and institutional and economic components of public relations and has its own requirements for these relations.

There is the difference between enterprise marketing activity carried out in a certain area for the promotion of the company's products and territorial marketing carried out in order to promote it within a single economic space, which includes not only the territory of the country but also the international aspects of the territory's functioning. For this purpose, commercial and non-commercial marketing is used, as well as all its types and varieties, because the essence of territorial marketing is complex. In any limited area, there is an intersection, localization, and polarization of economic interests of both the population of this area and those who live outside it. This is an objective precondition for the inconsistency of interests, the emergence of contradictions, and the search for ways for their harmonization.

The conditions for forming the area marketing potential, its essence, functions are explored and formulated; the infrastructure model is offered; features of forming the model in industrial, social, and marketinstitutional spheres are highlighted. The method of integral indicator estimation for territorial marketing stable functioning, where indicators of financial stability, business activity, profitability, technological, intellectual, social, and environmental sustainability are used, is proposed.

\section{References:}

Anoshkin, A. (2014). Marketing territorii v internet-prostranstve [Marketing of territory in the internet-space]. Problemy sovremennoi ekonomiki, 2, 273-275.

Bagautdinova, N. (2012). The regional development strategy based on territorial marketing (the case of Russia). World Applied Sciences Journal, 18(18), 179-184.

Bendle, N. T., \& Wang, X. S. (2017). Marketing accounts. International Journal of Research in Marketing, 34, 604-621.

Black, John, Hashimzade Nigar, \& Myles Gareth (2009). A Dictionary of Economics. Oxford University Press. Retrieved from: http:9/www.oxfordreference.com/view/10.1093/acref/9780199237043.001.0001/acref9780199237043

Chandler, A. D. (2015). Strategy and Structure. Cambridge MIT Press, 480 p.

Grishina, L. O., Yefimova, G. V., Grishina, N. V. (2011). Assessment of the region economic potential while shaping its development strategy [Otsinka ekonomichnoho potentsialu rehionu pry formuvanni stratehii yoho rozvytku]. Scientific notes Kirovohrad National Technical University. Economic sciences. Retrieved from: http://nbuv.gov.ua/ UJRN/Npkntu_e_2011_19_17

Isoraite, M. (2009). Theoretical aspects of marketing strategy. Ekonomika ir vadyba: aktualijos ir perspektyvos, 1(14), 114-125.

Kozhukhivska, R., Parubok, N., Petrenko, N., Podzihun, S. and Udovenko, I. (2017). Methods of assessment of efficiency of creating regional innovative clusters for dynamic development of economics. Investment Management and Financial Innovations, 14(3), 302-312. doi:10.21511/imfi.14(3-2).2017.01.

Megri, Z., Bencherif, F. (2014). The effect of territorial marketing on city image valuation: an exploratory study in Algeria. International Journal of Marketing Studies, 4(6), 145. 
Popkova, E. G., Dubova, Ju. I. and Romanova, M. K. (2013). Designing the territorial marketing strategy on the principles of cluster policies. World Applied Sciences Journal, 22(4), 571-576.

Runielt, R. P. (2014). Strategy, structure, and economic performance. Boston: Harvard Business School Press, 462 p. Simeon, M. I., Buonincontri, P. (2011). Cultural event as a territorial marketing tool: The case of the Ravello Festival on the Italian Amalfi Coast. Journal of Hospitality Marketing \& Management, 3-4(20), 385-406.

Schubert, T. (2010). Marketing and organizational Innovations in entrepreneurial innovation processes and their relation to market structure and firm characteristics. Review of Industrial Organization, 2(36), 189-212.

Taraniuk, K. V. \& Taraniuk, L. M. (2016). Methodological basis of risk management system with regard to industrial activities in the course of radical transformations. Economic annals - XXI, 156(1-2), 67-70.

Venter, P. \& Jansen van Rensburg, M. (2014). Strategic marketing: theory and applications for competitive advantage. Oxford University Press.

Voynarenko, M. P., Bohatchyk, L. A. (2014). Cluster tools usage for subregional strategies development to improve the competitiveness of regional economy [Vykorystannia klasternoho instrumentariyu pry rozrobtsi subrehionalnykh stratehiy pidvyshchennya konkurentospromozhnosti ekonomiky rehioniv]. Aktualni problemy ekonomiky. Retrieved from: http://nbuv.gov.ua/UJRN/ape_2014_8_22 